N. Danyliuk, T. Tatarchuk, A. Shyichuk

\title{
Estimation of Photocatalytic Degradation Rate Using Smartphone Based Analysis
}

\author{
Vasyl Stefanyk Precarpathian National University, Ivano-Frankivsk, Ukraine, e-mail: danyliuk.nazariy@gmail.com
}

\begin{abstract}
A simple approach to test photocatalyst activity has been described. Photocatalytic degradation of a model dye was measured with using a smartphone. The color changes were registered directly in the micro-photoreactor. The model dye Rhodamine B was degraded under UV irradiation $(365 \mathrm{~nm})$. The effect of $\mathrm{H}_{2} \mathrm{O}_{2}$ concentration and titanium dioxide photocatalyst dosage has been studied. Among three color systems, RGB, CIE L*a*b* and HSV, the first one proved to be the most suitable for the dye determination. The reference measurements were carried out with a UV-Vis spectrophotometer. Two smartphones and two tablets with different camera resolution have been examined. The best calibration curve was obtained using Samsung Galaxy A6 smartphone with a $16 \mathrm{MP}$ camera. The t-test has showed with a $95 \%$ confidence that there are no significant differences between the dye concentrations measured with the smartphone and spectrophotometer. The values of relative standard deviation of the smartphone measurements were less than $0.5 \%$. Therefore, the proposed method for fast estimation of photocatalyst activity can be used in control of advanced oxidation reactions.
\end{abstract}

Key words: smartphone, Rhodamine B, photocatalyst, LED, photodegradation.

Received 29 October 2020; Accepted 15 December 2020.

\section{Introduction}

The recent trend in analytical chemistry is to make the measuring techniques more feasible and wide spread. Mobile devices are increasingly used to simplify chemical analysis. Nowadays smartphone is a very common device giving access to a huge amount of information. Smartphone technology has not yet reached its evolutionary peak. Smartphones provide many opportunities to improve medical diagnostics, chemical analysis and environmental control [1]. For that reason, smartphones attract increasing attention of researchers. The confirmation is the growing number of scientific publications on smartphone-based analytical methods. The numbers of publications related to the smartphonebased and smartphone-controlled analysis are shown in Fig. 1. Probably, the number of the studies on detecting food toxins and environmental contaminants will increase in the coming years.

For chemical analysis purposes, smartphones can be combined with paper test strips, chip-based sensors and many other detectors. For example, test strips have been combined with a smartphone to quantify bacteria in food [2]. There are various smartphone-based systems for detecting food and water contaminants, including heavy metals $[3,4]$, microorganisms and parasites $[5,6]$.

The analysis of substances by a smartphone is based mainly on colorimetric [3,4], fluorescent [7], luminescent [6] and electrochemical [8] methods (Table 1). Smartphone-based assays are already used in healthcare, food control $[9,10]$ and environmental protection [11]. Smartphone applications [12, 13] allow detecting and quantifying many analytes. The specialized applications perform complex analytical calculations and can be used by non-professionals. 


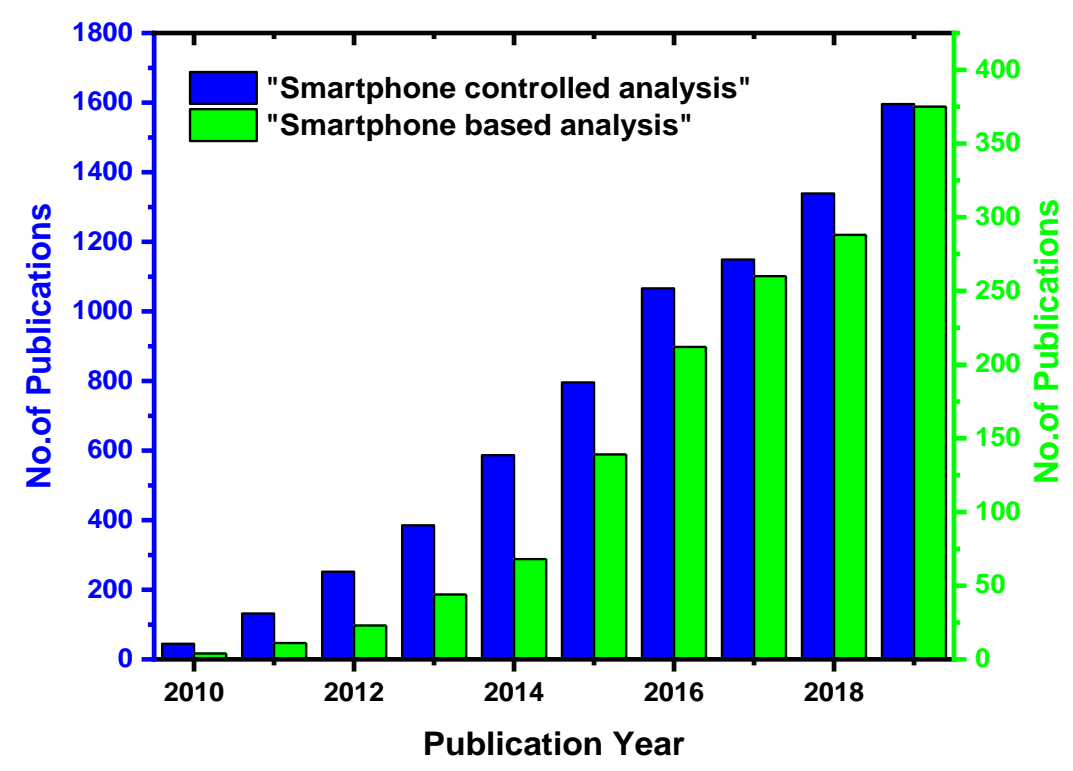

Fig. 1. The number of scientific publications related to the smartphone-based and the smartphone-controlled analysis for the last 10 years (according to the Scopus ${ }^{\circledR}$ database, search date: 01-10-2020).

Table 1

The examples of smartphone-based analysis for food and water quality control

\begin{tabular}{|c|c|c|c|}
\hline Analysis & Detection target & Limit of detection (LOD) or linear range (LR) & Ref. \\
\hline \multirow[t]{13}{*}{ Colorimetric analysis } & Fe in bioethanol fuel & LOD: $0.5 \mathrm{mg} / \mathrm{ml}$ & [4] \\
\hline & Mercury ion & LOD: $50 \mathrm{nM}$ & [3] \\
\hline & Fluoride & LR: $0.0-2.0 \mathrm{mg} / \mathrm{l}$ & [18] \\
\hline & Chlorine & LR: $0.06-2.0 \mathrm{ppm}$ & [20] \\
\hline & Protein & LOD: $1.0 \%$ & [10] \\
\hline & Phenol index & LOD: $2 \mu \mathrm{g} / \mathrm{L}$ & [26] \\
\hline & Fluoride & LOD: $1.23 * 10^{-4} \mathrm{mg} / \mathrm{L}$ & [19] \\
\hline & Sibutramine & LOD: $1.15 \mu \mathrm{M}$ & [24] \\
\hline & Phosphate ion & LOD: $0.09 \mu \mathrm{M}$ & [21] \\
\hline & Mercury ion & LOD: $0.28 \mathrm{ng} / \mathrm{mL}$ & [22] \\
\hline & Chlorine & LOD: $5.00 * 10^{-2} \mathrm{mg} / \mathrm{L}$ & \multirow[t]{2}{*}{ [23] } \\
\hline & Nitrite & LOD: $8.60 * 10^{-3} \mathrm{mg} / \mathrm{L}$ & \\
\hline & Hydrogen peroxide & LOD: $1.7 \mathrm{mg} / \mathrm{L}$ & [27] \\
\hline $\begin{array}{l}\text { Bioluminescence } \\
\text { analysis }\end{array}$ & P. fluorescens M3A & LOD: $7.9 \times 10^{6} \mathrm{CFU} / \mathrm{ml}$ & [28] \\
\hline \multirow{2}{*}{ Luminescence analysis } & Escherichia coli & LOD: $70 \mathrm{CFU} / \mathrm{ml}$ & \multirow[t]{2}{*}{ [6] } \\
\hline & Staphylococcus aureus & LOD: $131 \mathrm{CFU} / \mathrm{ml}$ & \\
\hline \multirow{2}{*}{ Fluorescence analysis } & Alkaline phosphatase & LOD: $0.078 \mathrm{mU} / \mathrm{mL}$ & [7] \\
\hline & Escherichia coli & LOD: 5 to $10 \mathrm{CFU} / \mathrm{mL}$ & [5] \\
\hline $\begin{array}{l}\text { Electrochemical } \\
\text { analysis }\end{array}$ & Hydrogen peroxide & LR: $0.0-0.429 \mu \mathrm{A} \mathrm{L} / \mathrm{mmol}$ & {$[8]$} \\
\hline
\end{tabular}

Photometric analysis is attractive due to its simplicity [14]. Unlike fluorescence-based sensors, colorimetric sensors may work without additional light sources, so the devices are small and portable. Typically, a colorimetric method uses changes in absorbance over a given wavelengths range. The color changes are captured by the smartphone camera. Different color space systems may be used: RGB, HSV or CIE L*a*b*. Colorimetric analysis is used to detect both organic substances (dyes, toxins, formaldehyde, etc.) [15-17] and inorganic substances (fluoride [18, 19], chlorine [20], nitrite, phosphates [21], $\mathrm{Fe}$ [4], $\mathrm{Cu}, \mathrm{Pb}, \mathrm{Hg}[3,22])$. Typical objects for analysis are water [23], food [24] and drinks [25] (Table 1).

The purpose of this work is to develop a feasible method for photocatalysts testing. A smartphone 
Table 2

Mobile devices used for testing

\begin{tabular}{|l|l|c|}
\hline Digital device & \multicolumn{1}{|c|}{ Model } & Camera \\
\hline Smartphone-1 & Samsung Galaxy A6 (SM-A600FN) 3/64Gb & $16 \mathrm{MP}$ \\
\hline Smartphone-2 & Samsung Galaxy S4 mini GT-i9192 & $8 \mathrm{MP}$ \\
\hline Tablet-1 & Asus ZenPad 7.0 16Gb & 5 MP \\
\hline Tablet-2 & Huawei MediaPad T3 7 3G & $2 \mathrm{MP}$ \\
\hline
\end{tabular}

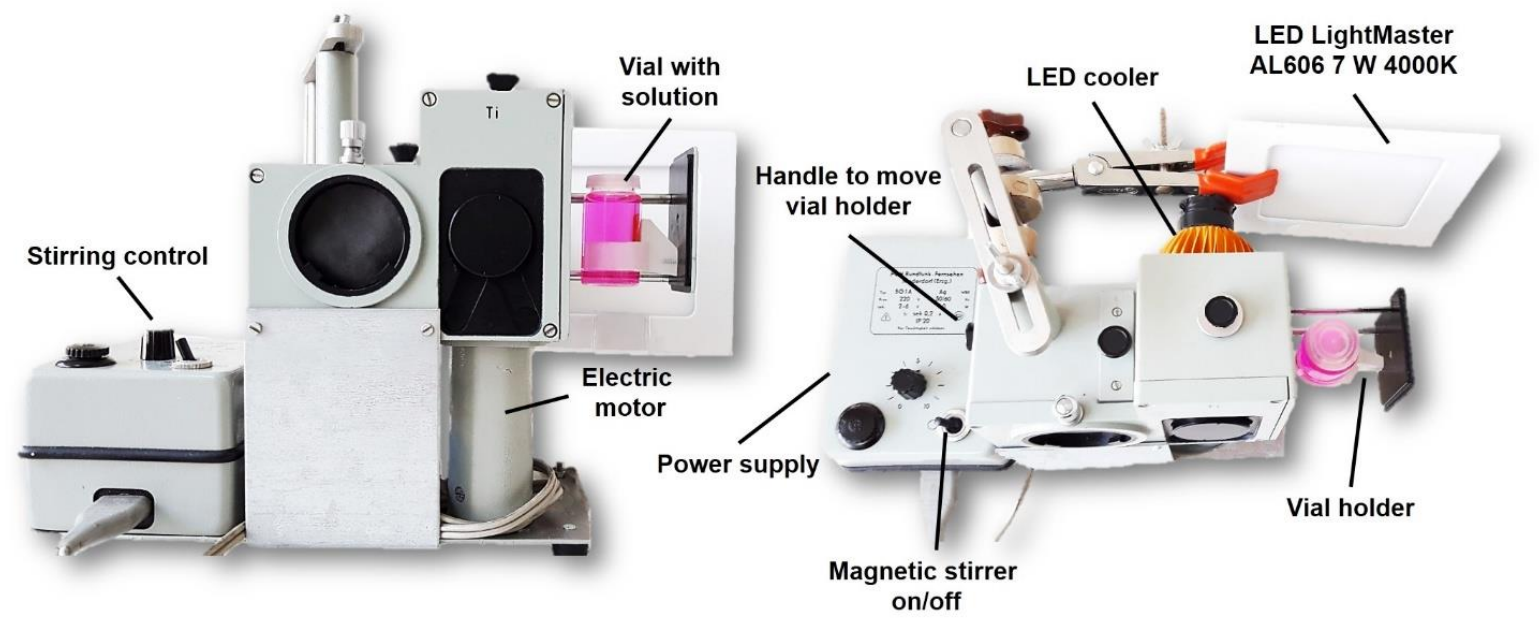

Fig. 2. General view of the micro-photoreactor.

provides fast and easy measurement of dye photodegradation rate. The exemplary photocatalyst was well-known titania Aeroxide P25 in the presence of hydrogen peroxide as a promoter. The Rhodamine B dye was as a model dye for the photodegradation. The optimal range of hydrogen peroxide concentration has been found. The photooxidation reaction was carried out in the microreactor described recently [29]. The microreactor has the following advantages: (i) small amounts of reagents and photocatalyst required; (ii) rapid replacement of the radiation source (depending on the model compound to degrade); (iii) low cost. The photooxidation rate measurements were performed using four portable devices in order to estimate a probable effect of camera parameters.

\section{Materials and methods}

\subsection{Photocatalyst and reagents}

Titania Aeroxide P25 (Degussa/Evonik, Germany) was used as photocatalyst. This material is widely used due to its high activity in many photocatalytic reaction. The commercial P25 photocatalyst contains mixture of $70-80 \%$ anatase and $20-30 \%$ rutile. The P25 catalyst has average BET surface area about $50 \mathrm{~m}^{2} / \mathrm{g}$ and average particle size of $30 \mathrm{~nm}$ [30]. The Rhodamine B (RhB) dye was obtained from Aldrich. Reagent grade hydrogen peroxide $(30 \%)$ from a local store of chemicals was diluted to $0.5 \mathrm{~mol} / \mathrm{L}$ stock solution.

\subsection{Mobile devices and spectrophotometer}

The mobile devices used for testing photooxidation rate are described in Table 2.

The UV-Vis spectrophotometer ULAB 102-UV with $5 \mathrm{~mm}$ glass cuvettes was used for the determination of Rhodamine B concentration [29].

\subsection{Micro-photoreactor}

Front view and top view of the micro-photoreactor are shown in Fig. 2. The volume of the round glass vial is $20 \mathrm{~mL}$. The UV radiation source is a $3 \mathrm{~W}$ light-emitting diode (UV-LED) with the narrow emission range from 365 to $370 \mathrm{~nm}$.

\subsection{Dye photodegradation tests}

The photodegradation experiments were carried out using $20 \mathrm{~mL}$ of aqueous solution of the $\mathrm{RhB}$ dye with the concentration of $5 \mathrm{mg} / \mathrm{L}$. The exact mass of $30 \mathrm{mg}$ of the P25 photocatalyst was added. The suspension was magnetically stirred for $20 \mathrm{~min}$ in the dark to reach adsorption equilibrium. The duration of the UV irradiation was $30 \mathrm{~min}$. Every $5 \mathrm{~min}$ the vial holder was pulled out and the vial images were captured with the mobile devices (Fig. 3). Finally, the suspension was centrifuged for $10 \mathrm{~min}$ at $4000 \mathrm{rpm}$, and the absorbance of the supernatant was measured at $560 \mathrm{~nm}$ on the spectrophotometer. 


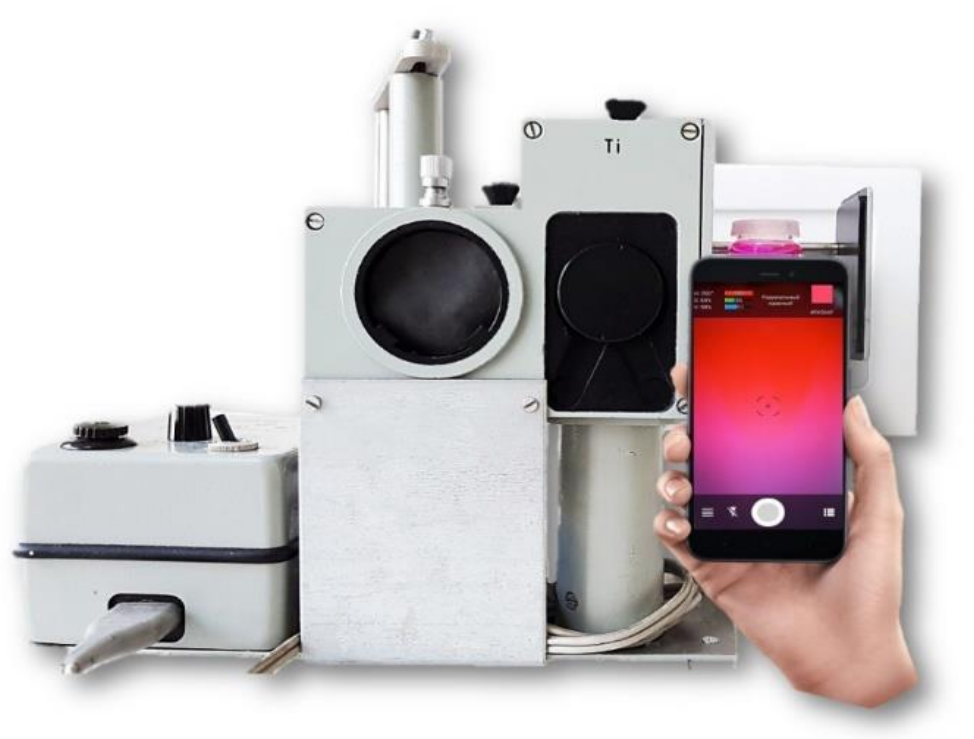

Fig. 3. Color measurements using smartphone camera.

Table 3

The comparison of various approaches for RGB data analysis

\begin{tabular}{|c|c|c|c|}
\hline Analyte & Digital device & Equation & Ref. \\
\hline phosphate & $\begin{array}{c}\text { scanner HP Scanjet } \\
\text { G2710 }\end{array}$ & $\begin{array}{l}A=-\log \left(\frac{R}{R_{0}}\right) \\
{[v]=\sqrt{\left(R-R_{0}\right)^{2}+\left(G-G_{0}\right)^{2}+\left(B-B_{0}\right)^{2}}}\end{array}$ & {$[31]$} \\
\hline $\begin{array}{l}\text { Iron (II/III) in } \\
\text { white wine }\end{array}$ & Microsoft 720p HD & $A=\log \left(\frac{B_{0}}{B_{x}}\right)$ & {$[32]$} \\
\hline $\begin{array}{l}\mathrm{KMnO}_{4}, \\
\mathrm{CoSO}_{4}, \mathrm{NiSO}_{4}, \\
\mathrm{CuSO}_{4}\end{array}$ & Smartphone & $\begin{array}{l}\left\langle I_{R G B}\right\rangle_{\text {std/unknown }}=\frac{R_{\text {pixel }}+G_{\text {pixel }}+B_{\text {pixel }}}{3} \\
\left\langle I_{R G B}\right\rangle_{p}=\log \left(\frac{\left\langle I_{R G B}\right\rangle_{\text {blank }}}{\left\langle I_{R G B}\right\rangle_{\text {std } / \text { unknown }}}\right)\end{array}$ & {$[33]$} \\
\hline RhB dye & Smartphone & $\mathrm{R}^{\prime}=\frac{\mathrm{R}}{\mathrm{R}+\mathrm{G}+\mathrm{B}} ; \quad \mathrm{G}^{\prime}=\frac{\mathrm{G}}{\mathrm{R}+\mathrm{G}+\mathrm{B}} ; \mathrm{B}^{\prime}=\frac{\mathrm{B}}{\mathrm{R}+\mathrm{G}+\mathrm{B}}$ & This work \\
\hline
\end{tabular}

\section{Results and discussion}

\subsection{Calibration curves obtained with color} measurements

To provide reproducibility of the color measurements, a probable impact of extraneous light should be minimized. For that reason, a bright white background was used for capturing images of the vial with the colored suspensions. The used 7W LED lamp with $4000 \mathrm{~K}$ color temperature consists of 30 LEDs and provides flat white background. As a result of the RhB dye degradation, the reaction mixtures changed color from bright pink to pale ping and further to dirty white. The color parameters of the captured images were obtained with using the mobile application Spectrum (available on the Play Market). This application works with various color systems, such as RGB, HSV, CIE
L*a*b*, CMYK, XYZ, RYB. Different approaches for analyzing raw RGB data have been reported in the literature (Table 3). We proposed new equations providing the best correlation coefficient $\left(\mathrm{R}^{2}\right)$ in a wide range of concentrations. The normalized red component $\mathrm{R}^{\prime}$ was calculated as the following: $\mathrm{R}^{\prime}=\frac{\mathrm{R}}{\mathrm{R}+\mathrm{G}+\mathrm{B}}$.

The exemplary color images captured for the $\mathrm{TiO}_{2}$ suspensions with different concentrations of the $\mathrm{RhB}$ dye are presented in Table 4. Three color models (RGB, CIE $\left.\mathrm{L}^{*} \mathrm{a} \mathrm{b}^{*}, \mathrm{HSV}\right)$ were applied to describe color changes. In the RGB color system, the increase of RhB concentration leads to increase in the Red component and decrease in the Green and Blue color components. So, the Red component of the color was used for the determination of the RhB dye. In the CIE L*a*b* color system, the parameters $L^{*}$ and $b^{*}$ do not show monotonic changes. The parameter $\mathrm{a}^{*}$ is rather increased. In the HSV color system, slight changes in the $\mathrm{S}$ and $\mathrm{V}$ parameters are 
Table 4

The color parameters of the RhB dye solutions with different concentrations (the solution volume was $20 \mathrm{~mL}$ and $\mathrm{TiO}_{2}$ dosage was $30 \mathrm{mg}$ )

\begin{tabular}{|c|c|c|c|c|c|c|c|c|c|c|c|}
\hline \multirow{2}{*}{$\begin{array}{c}\mathrm{C}(\mathrm{RhB}), \\
\mathrm{mg} / \mathrm{L}\end{array}$} & \multirow{2}{*}{ Image } & \multicolumn{4}{|c|}{ RGB } & \multicolumn{3}{|c|}{$\operatorname{CIE} \mathbf{L}^{*} \mathbf{a}^{*} \mathbf{b}^{*}$} & \multicolumn{3}{|c|}{ HSV } \\
\hline & & $\mathbf{R}$ & $\mathbf{G}$ & B & $\mathbf{R}^{\prime}$ & $\mathbf{L}^{*}$ & $\mathbf{a}^{*}$ & $\mathbf{b}^{*}$ & $\mathbf{H}$ & $\mathbf{S}$ & V \\
\hline \multicolumn{12}{|c|}{ Smartphone-1 } \\
\hline 0 & & 172 & 161 & 155 & 0.352 & 68.5 & 2.9 & 4.5 & 21 & 9 & 69 \\
\hline 1 & & 192 & 122 & 132 & 0.430 & 58.8 & 28.6 & 6.0 & 351 & 36 & 75 \\
\hline 2 & & 206 & 112 & 130 & 0.460 & 58.3 & 38.9 & 6.8 & 348 & 45 & 80 \\
\hline 3 & & 220 & 112 & 127 & 0.479 & 60.2 & 43.6 & 11.4 & 351 & 49 & 86 \\
\hline 4 & & 207 & 95 & 107 & 0.506 & 54.6 & 45.4 & 14.9 & 353 & 54 & 81 \\
\hline 5 & & 220 & 96 & 107 & 0.520 & 56.7 & 49.5 & 18.2 & 354 & 56 & 86 \\
\hline \multicolumn{12}{|c|}{ Smartphone-2 } \\
\hline 0 & & 145 & 117 & 52 & 0.462 & 50.4 & 4.2 & 35.8 & 40 & 60 & 56 \\
\hline 1 & & 175 & 90 & 93 & 0.489 & 48.5 & 34.8 & 14.1 & 357 & 48 & 68 \\
\hline 2 & & 184 & 79 & 93 & 0.517 & 47.7 & 43.7 & 13.2 & 352 & 57 & 72 \\
\hline 3 & & 183 & 70 & 90 & 0.534 & 45.8 & 47.3 & 12.5 & 349 & 61 & 71 \\
\hline 4 & & 221 & 81 & 107 & 0.540 & 54.3 & 56.5 & 15.0 & 348 & 63 & 86 \\
\hline 5 & & 171 & 59 & 71 & 0.568 & 41.5 & 46.6 & 18.0 & 353 & 65 & 67 \\
\hline \multicolumn{12}{|l|}{ Tablet-1 } \\
\hline 0 & & 128 & 118 & 106 & 0.364 & 50.2 & 1.6 & 7.9 & 32 & 17 & 50 \\
\hline 1 & & 140 & 68 & 105 & 0.447 & 39.1 & 35.1 & -7.3 & 329 & 51 & 54 \\
\hline 2 & & 124 & 35 & 91 & 0.496 & 30.0 & 43.8 & -12.4 & 322 & 71 & 48 \\
\hline 3 & & 142 & 16 & 89 & 0.575 & 31.4 & 54.0 & -8.6 & 325 & 88 & 55 \\
\hline 4 & & 155 & 14 & 66 & 0.660 & 33.2 & 55.6 & 9.4 & 337 & 90 & 60 \\
\hline 5 & & 124 & 12 & 71 & 0.599 & 26.7 & 48.4 & -4.1 & 328 & 90 & 48 \\
\hline \multicolumn{12}{|l|}{ Tablet-2 } \\
\hline 0 & & 195 & 163 & 104 & 0.422 & 68.6 & 4.2 & 33.9 & 38 & 45 & 76 \\
\hline 1 & & 220 & 135 & 130 & 0.454 & 65.0 & 31.9 & 16.5 & 3 & 40 & 86 \\
\hline 2 & & 220 & 142 & 156 & 0.425 & 67.2 & 31.4 & 4.9 & 349 & 35 & 86 \\
\hline 3 & & 242 & 145 & 162 & 0.441 & 70.6 & 38.5 & 6.9 & 349 & 40 & 94 \\
\hline 4 & & 228 & 124 & 149 & 0.455 & 64.2 & 42.8 & 4.7 & 345 & 45 & 89 \\
\hline 5 & & 242 & 136 & 156 & 0.453 & 68.6 & 42.4 & 7.3 & 348 & 43 & 94 \\
\hline
\end{tabular}

observed. Instead, the parameter $\mathrm{H}$ initially increases and then has a rather stable value. Thus, the calibration curves have been drawn using the parameter R' (Fig. 4). It can be seen that the calibration lines and coefficients $\mathrm{R}^{2}$ are dependent on digital camera used (Fig. 4). In the first approach, better camera resolution provides larger values of the $\mathrm{R}^{2}$ parameter. For example, the
Smartphone-1 with a $12 \mathrm{MP}$ camera provides $\mathrm{R}^{2}=0.996$, while Tablet- 2 with a $2 \mathrm{MP}$ camera provides $\mathrm{R}^{2}=0.436$. The Smartphone- 2 also provides rather high value $\mathrm{R}^{2}=$ 0.979 . Therefore, the $8 \mathrm{MP}$ camera is also suitable for the RhB determination. The kinetic measurements on RhB photooxidation were performed with the Smartphone-1 providing the best calibration line. 


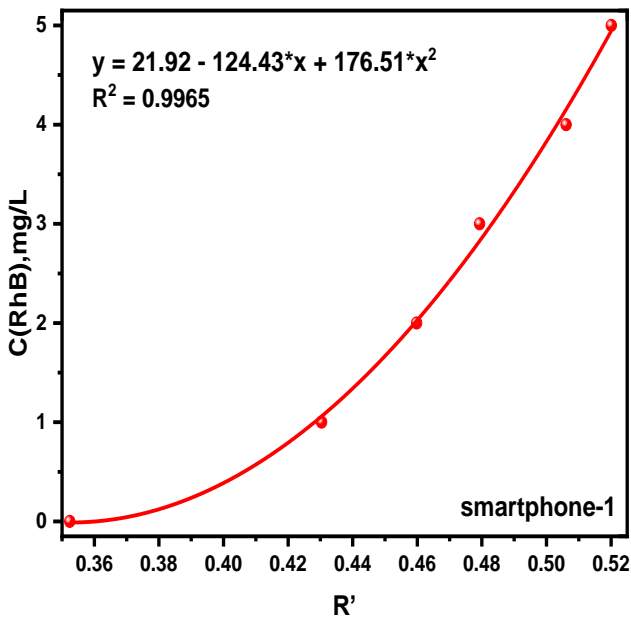

a

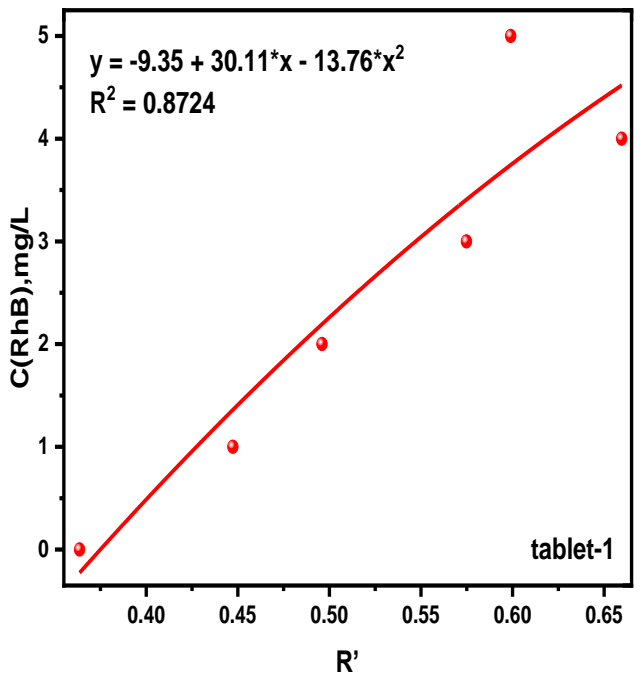

c

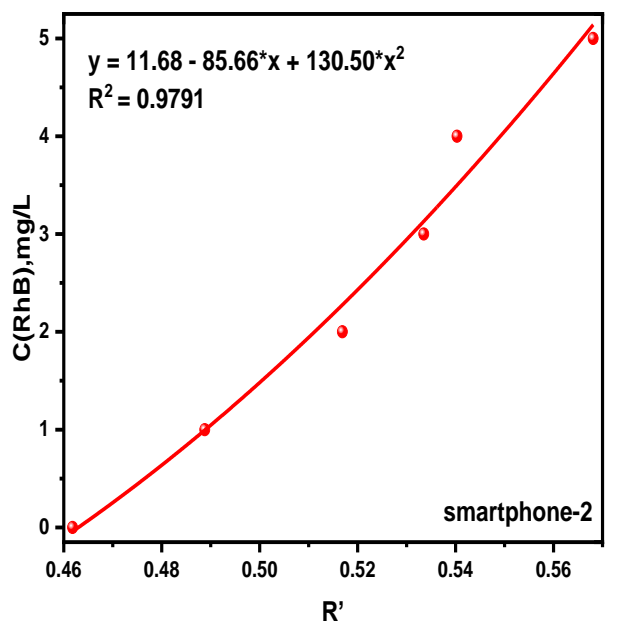

b

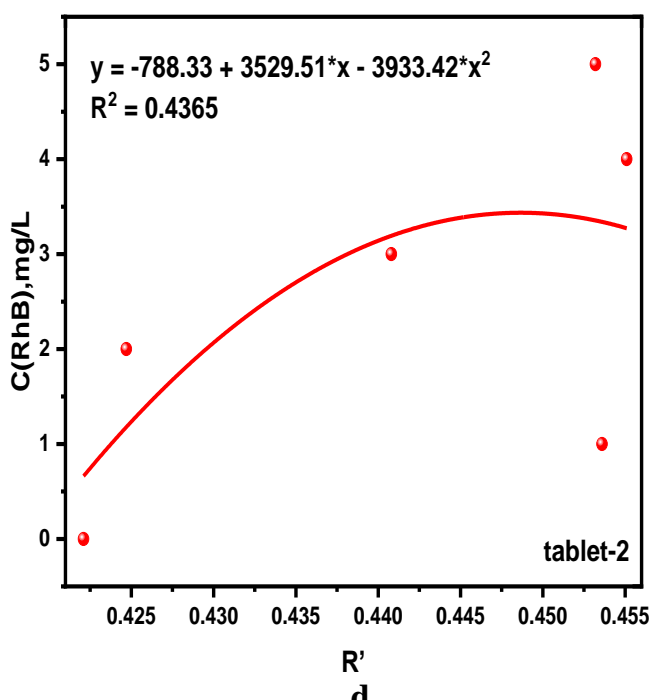

d

Fig. 4. Calibration curves with the normalized R' parameter.

Table 5

Color of the solutions and the values of parameter $\mathrm{R}^{\prime}=\frac{\mathrm{R}}{\mathrm{R}+\mathrm{G}+\mathrm{B}}$ during photodegradation of the $\mathrm{RhB}$ dye activated with $\mathrm{TiO}_{2}$ and $\mathrm{H}_{2} \mathrm{O}_{2}$. The images were captured by Smartphone-1.

\begin{tabular}{|c|c|c|c|c|c|c|c|}
\hline $\mathbf{C}\left(\mathbf{H}_{2} \mathbf{O}_{2}\right)$ & $\mathbf{0 ~ m i n}$ & $\mathbf{5 ~ m i n}$ & $\mathbf{1 0} \mathbf{~ m i n}$ & $\mathbf{1 5} \mathbf{~ m i n}$ & $\mathbf{2 0 ~} \mathbf{m i n}$ & $\mathbf{2 5} \mathbf{~ m i n}$ & $\mathbf{3 0} \mathbf{~ m i n}$ \\
\hline $0 \mathrm{mM}$ & 0.520 & 0.524 & 0.5152 & 0.5075 & 0.4987 & 0.480 & 0.467 \\
\hline $5 \mathrm{mM}$ & 0.5392 & 0.502 & 0.4829 & 0.4635 & 0.4243 & 0.394 & 0.386 \\
\hline $10 \mathrm{mM}$ & 0.5394 & 0.489 & 0.4836 & 0.4454 & 0.4217 & 0.386 & 0.382 \\
\hline $15 \mathrm{mM}$ & 0.5294 & 0.507 & 0.4889 & 0.4619 & 0.4311 & 0.416 & 0.387 \\
\hline $25 \mathrm{mM}$ & 0.5274 & 0.519 & 0.4851 & 0.4699 & 0.4325 & 0.410 & 0.387 \\
\hline
\end{tabular}




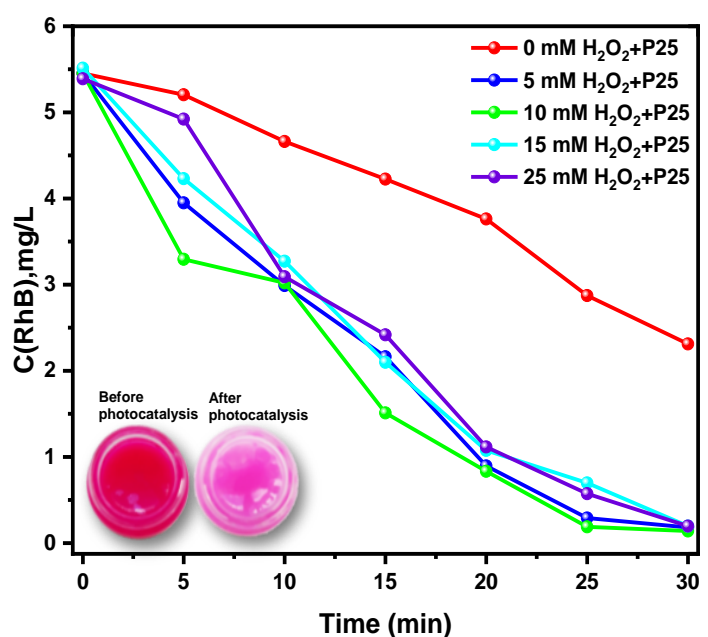

a

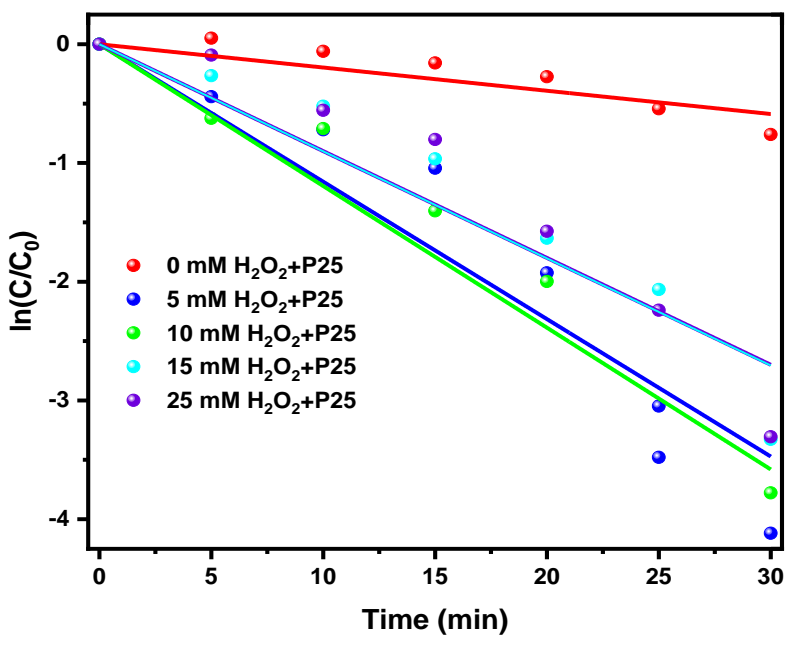

b

Fig. 5. (a) Kinetic curves of the RhB dye photodegradation; (b) transformation according the first-order kinetic model. The initial conditions were the following: $\mathrm{C}_{0}(\mathrm{RhB})=5 \mathrm{mg} / \mathrm{L}: \mathrm{m}\left(\mathrm{TiO}_{2}\right)=30 \mathrm{mg}$; $\mathrm{V}($ solution $)=20 \mathrm{~mL}$;

$$
\mathrm{C}\left(\mathrm{H}_{2} \mathrm{O}_{2}\right)=0-25 \mathrm{mM} \text {. }
$$

Table 6

The parameters of the first-order kinetic model for the RhB photodegradation. The initial conditions were the same as in Fig. 5

\begin{tabular}{|c|c|c|}
\hline $\mathrm{H}_{2} \mathrm{O}_{2}$ concentration & $\mathrm{k}\left(\mathrm{min}^{-1}\right)$ & $\mathrm{R}^{2}$ \\
\hline $0 \mathrm{mM}$ & 0.0195 & 0.891 \\
\hline $5 \mathrm{mM}$ & 0.1157 & 0.959 \\
\hline $10 \mathrm{mM}$ & 0.1193 & 0.975 \\
\hline $15 \mathrm{mM}$ & 0.0901 & 0.959 \\
\hline $25 \mathrm{mM}$ & 0.0899 & 0.950 \\
\hline
\end{tabular}

\subsection{Measurements of photocatalytic oxidation} rate

The degree of photocatalyst activity depends on several parameters, such as light intensity, reactor shape, contaminant concentration, solution volume, photocatalyst dosage, $\mathrm{pH}$, and others [34-39]. The final products of photocatalytic degradation of the $\mathrm{RhB}$ dye are water and carbon dioxide [40]. In this study, the RhB concentration has been $5 \mathrm{mg} / \mathrm{L}$ to ensure complete dye removal. The mass of $\mathrm{TiO}_{2}$ was $30 \mathrm{mg}$. Larger doses of photocatalysts could block the UV-radiation, necessary to destroy $\mathrm{RhB}$ [29]. The experimental images captured under the RhB photodegradation are presented in Table 5. Kinetics of the $\mathrm{RhB}$ photodegradation is depicted in Fig. 5a. The presence of $\mathrm{H}_{2} \mathrm{O}_{2}$ leads to increase of photodegradation rate. Complete degradation of the $\mathrm{RhB}$ dye occurs after 30 minutes. The kinetics is rather well fitted by the first-order model. The obtained rate constants are listed in Table 6 . It can be seen that the rate constant increases with increasing $\mathrm{H}_{2} \mathrm{O}_{2}$ dosing, reaching a maximum at a concentration of $10 \mathrm{mM} \mathrm{H}_{2} \mathrm{O}_{2}$. The subsequent increase of $\mathrm{H}_{2} \mathrm{O}_{2}$ concentration leds to decrease in $\mathrm{RhB}$ photodegradation. It can be explained by recombination of large amount of hydroxyl radicals with $\mathrm{H}_{2} \mathrm{O}_{2}$ molecules.

Spectra of the final solutions were registered with the UV-Vis spectrophotometer (Fig. 6). The reliability of the smartphone measurements was confirmed by a t-test. The t-test at $95 \%$ confidence did not show differences between the concentrations measured by the smartphone1 and the spectrophotometer. The data summarized in Table 7 show a good agreement between the two devices. The mechanism of $\mathrm{RhB}$ photodegradation is

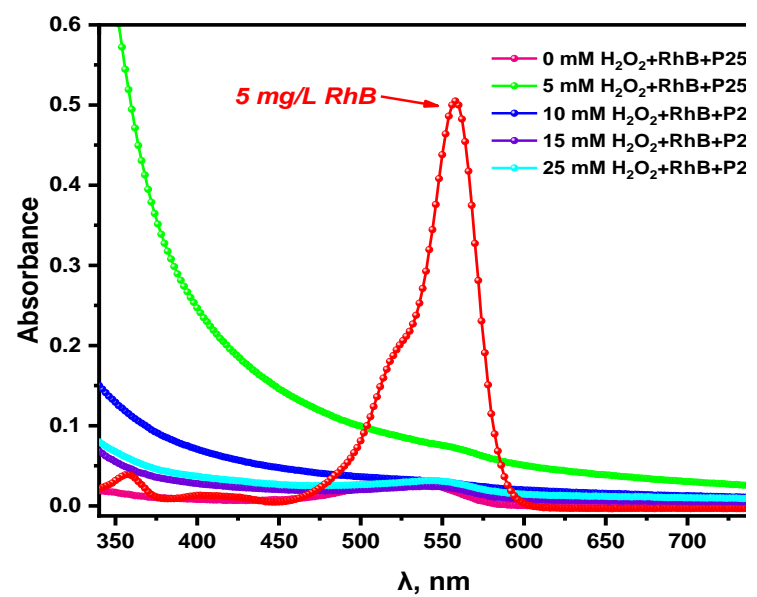

Fig. 6. Exemplary spectra of the RhB dye solutions after photodegradation. 
Table 7

Degree of the RhB dye photodegradation (after 30 min irradiation) measured with the two devices and Relative Standard Deviation (RSD) of the smartphone measurements $(n=3)$.

\begin{tabular}{|c|c|c|}
\hline \multicolumn{2}{|c|}{ Photodegradation degree, $\%$} & \multirow{2}{*}{ RSD, \% } \\
\hline Spectrophotometer & Smartphone-1 & 0.17 \\
\hline 71.25 & 73.63 & 0.12 \\
\hline 97.70 & 98.50 & 0.20 \\
\hline 98.90 & 98.70 & 0.45 \\
\hline 95.80 & 96.49 & 0.48 \\
\hline
\end{tabular}

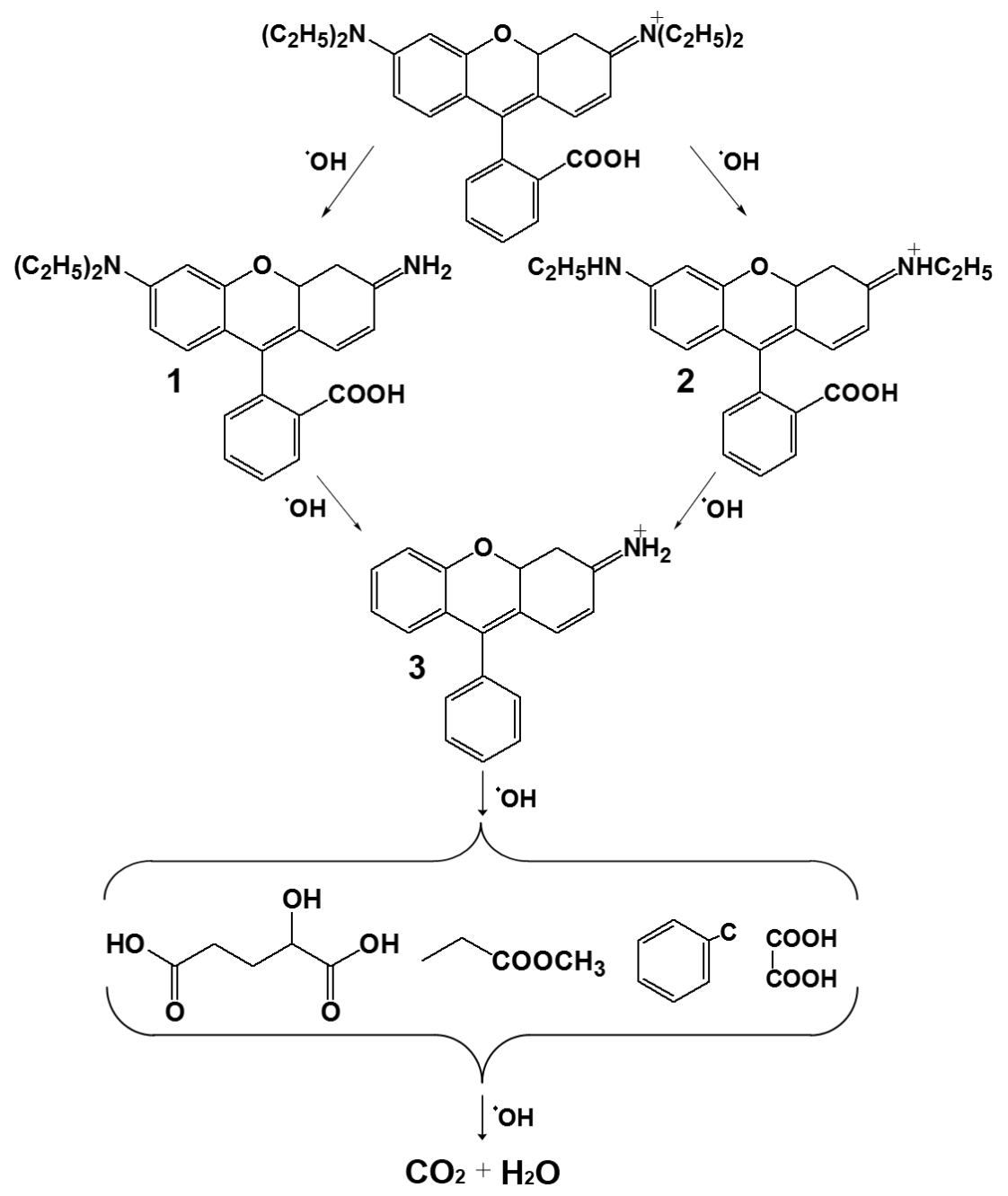

Fig. 7. The mechanism of RhB photodegradation in the presence of $\mathrm{P} 25$ and $\mathrm{H}_{2} \mathrm{O}_{2}$.

presented in Fig. 7. At first, auxochrome ethyl groups are detached from amino groups. As a result, the deethylated products 1-3 are formed. Second, carboxyl group is lost. The next stage is decomposition of chromophore core and formation of low molecular acidic compounds. Finally, carbon dioxide and water are formed.

\section{Conclusions}

Currently, smartphones are well used in analytical applications. Typically, quantitative determination is based on images recorded using a smartphone camera. In the present work, smartphone was used to study photodegradation of the $\mathrm{RhB}$ dye in the presence of the P25 titania photocatalyst and $\mathrm{H}_{2} \mathrm{O}_{2}$. The main advantage of this method is that the kinetic lines were registered without taking aliquots for the analysis. The microreactor uses small amount of the $\mathrm{TiO}_{2}$ photocatalyst. The Samsung Galaxy A6 smartphone showed very good repeatability in the $\mathrm{RhB}$ dye determination. Calibration curve for the mixtures of the $\mathrm{RhB}$ dye with the $\mathrm{TiO}_{2}$ 
catalyst were determined for the $\mathrm{RhB}$ concentration up to $5.0 \mathrm{mg} / \mathrm{L}$ with correlation coefficient $\mathrm{R}^{2}=0.996$. The relative standard deviation ranged from 0.12 to $0.48 \%$. It was found that $\mathrm{H}_{2} \mathrm{O}_{2}$ accelerates the dye photodegradation. However, the accelerating effect is decreased at high concentrations of $\mathrm{H}_{2} \mathrm{O}_{2}$ because the formed hydroxyl radicals react with the excess of $\mathrm{H}_{2} \mathrm{O}_{2}$ molecules.

\section{Acknowledgements}

N. Danyliuk and T. Tatarchuk thank the Ministry of Education and Science of Ukraine for financial support in the framework of Ukrainian-Polish bilateral project "Photocatalytic hybrid systems for water purification" (0120U104158). T. Tatarchuk acknowledge Professor W.
Macyk (Jagellonian University, Krakow, Poland) for a productive discussion. A. Shyichuk thanks the Ministry of Education and Science of Ukraine for financial support in the framework of project no. 0120 U102035.

Danyliuk N. - BSc, leading specialist at the Educational and Scientific Center of Material Science and Nanotechnology;

Tatarchuk T. - PhD in Chemistry, Associate Professor of the Chemistry Department, Director of Educational and Scientific Center of Material Science and Nanotechnology;

Shyichuk A. - Doctor of Chemical Sciences, Professor of the Chemistry Department.

[1] S. Srivastava, S. Vaddadi, S. Sadistap, Appl. Water Sci. 8 (2018) (doi:10.1007/s13201-018-0780-0).

[2] H. Liu, F. Zhan, F. Liu, M. Zhu, X. Zhou, D. Xing, Biosens. Bioelectron 62, 38 (2014) (doi:10.1016/j.bios.2014.06.020).

[3] G.H. Chen, W.Y. Chen, Y.C. Yen, C.W. Wang, H.T. Chang, C.F. Chen, Anal. Chem. 86, 6843 (2014) (doi:10.1021/ac5008688).

[4] A.F. João, A.L. Squissato, G.M. Fernandes, R.M. Cardoso, A.D. Batista, R.A.A. Muñoz, Microchem. J. 146, 1134 (2019) (doi:10.1016/J.MICROC.2019.02.053).

[5] H. Zhu, U. Sikora, A. Ozcan, Analyst. 137, 2541 (2012) (doi:10.1039/c2an35071h).

[6] A. Irhas Robby, S. Gi Kim, U. Han Lee, I. In, G. Lee, S. Young Park, Chem. Eng. J. 126351 (2020) (doi:10.1016/j.cej.2020.126351).

[7] L. Hou, Y. Qin, J. Li, S. Qin, Y. Huang, T. Lin, L. Guo, F. Ye, S. Zhao, Biosens. Bioelectron. 143, 111605 (2019) (doi:10.1016/j.bios.2019.111605).

[8] J.T.C. Barragan, L.T. Kubota, Electrochim. Acta. 341, 136048 (2020) (doi:10.1016/j.electacta.2020.136048).

[9] P.S. Liang, T.S. Park, J.Y. Yoon, Sci. Rep. 4, 4 (2014) (doi:10.1038/srep05953).

[10] A.F.S. Silva, F.R.P. Rocha, Food Control. 115, 107299 (2020) (doi:10.1016/j.foodcont.2020.107299).

[11] G.K. Özdemir, A. Bayram, V. Kiliç, N. Horzum, M.E. Solmaz, Anal. Methods 9, 579 (2017) (doi:10.1039/c6ay03073d).

[12] M. Trojanowicz, Instrumental Innovations and 5, 2 (2017) (doi:10.4172/2329-6798.1000).

[13] S. Álvaro, G. Marín, S. Vincent, Á.G. Marín, W. Van Hoeve, P. García-sánchez, N. Convine, A. Rosserjames, M. Tyler, K. Bandoo, L. Warncke, A. Lee, V. Vogel, Lab Chip. 154491 (2013) (doi:10.1039/c2lc41193h).

[14] R.H. Tang, H. Yang, J.R. Choi, Y. Gong, S.S. Feng, B. Pingguan-Murphy, Q.S. Huang, J.L. Shi, Q.B. Mei, F. Xu, Crit. Rev. Biotechnol. 37411 (2017) (doi:10.3109/07388551.2016.1164664).

[15] T. Tatarchuk, M. Naushad, J. Tomaszewska, P. Kosobucki, M. Myslin, H. Vasylyeva, P. Ścigalski, Environ. Sci. Pollut. Res. 2726681 (2020) (doi:10.1007/s11356-020-09043-1).

[16] P. Taylor, M. Naushad, A. Mittal, M. Rathore, V. Gupta37, (2014) (doi:10.1080/19443994.2014.904823).

[17] M. Naushad, Chem. Eng. J. 235, 100 (2014) (doi:10.1016/j.cej.2013.09.013).

[18] S. Levin, S. Krishnan, S. Rajkumar, N. Halery, P. Balkunde, Sci. Total Environ. 551-552, 101 (2016) (doi:10.1016/j.scitotenv.2016.01.156).

[19] I. Hussain, K.U. Ahamad, P. Nath, Anal. Chem. 89, 767 (2017) (doi:10.1021/acs.analchem.6b03424).

[20] S. Sumriddetchkajorn, K. Chaitavon, Y. Intaravanne, Sensors Actuators B Chem. 191, 561 (2014) (doi:10.1016/J.SNB.2013.10.024).

[21] X. Li, B. Liu, Z. Hu, P. Liu, K. Ye, J. Pan, X. Niu, Environ. Res. 189, 109921 (2020) (doi:10.1016/j.envres.2020.109921).

[22] W. Xiao, M. Xiao, Q. Fu, S. Yu, H. Shen, H. Bian, Y. Tang, Sensors (Switzerland) 16, (2016) (doi:10.3390/s16111871).

[23] M. Sargazi, M. Kaykhaii, Spectrochim. Acta - Part A Mol. Biomol. Spectrosc. 227, 117672 (2020) (doi:10.1016/j.saa.2019.117672).

[24] K. Chaisiwamongkhol, S. Labaidae, S. Pon-in, S. Pinsrithong, T. Bunchuay, A. Phonchai, Microchem. J. 158, 105273 (2020) (doi:10.1016/j.microc.2020.105273).

[25] J.R. Choi, Z. Liu, J. Hu, R. Tang, Y. Gong, S. Feng, H. Ren, T. Wen, H. Yang, Z. Qu, B. Pingguan-Murphy, F. Xu, Anal. Chem. 88, 6254 (2016) (doi:10.1021/acs.analchem.6b00195).

[26] A. Shahvar, M. Saraji, D. Shamsaei, Microchem. J. 154, 104611 (2020) (doi:10.1016/j.microc.2020.104611).

[27] M.J.A. Lima, M.K. Sasaki, O.R. Marinho, T.A. Freitas, R.C. Faria, B.F. Reis, F.R.P. Rocha, Microchem. J. 157, 105042 (2020) (doi:10.1016/j.microc.2020.105042). 
[28] H. Kim, Y. Jung, I.J. Doh, R.A. Lozano-Mahecha, B. Applegate, E. Bae, Sci. Rep. 7, 1 (2017) (doi:10.1038/srep40203).

[29] N.V. Danyliuk, T.R. Tatarchuk, A.V. Shyichuk, Phys. Chem. Solid State. 2, 338 (doi:https://doi.org/10.15330/pcss.21.2.338-346).

[30] Z. Shayegan, C.S. Lee, F. Haghighat, J. Environ. Chem. Eng. 7, 103390 (2019) (doi:10.1016/j.jece.2019.103390).

[31] H. Colzani, Q.E.A.G. Rodrigues, C. Fogaça, J.L.N. Gelinski, E.R. Pereira-Filho, E.M. Borges, Um exemplo didático para ensino de química, 40, 833 (2017) (doi:10.21577/0100-4042.20170035).

[32] J.H. Santos Neto, I.S.A. Porto, M.P. Schneider, A.M.P. dos Santos, A.A. Gomes, S.L.C. Ferreira, Talanta. 194, 86 (2019) (doi:10.1016/J.TALANTA.2018.09.102).

[33] S. Šafranko, P. Živković, A. Stanković, M. Medvidović-Kosanović, A. Széchenyi, S. Jokić, J. Chem. Educ. 96, 1928 (2019) (doi:10.1021/acs.jchemed.8b00920).

[34] I.F. Mironyuk, L.M. Soltys, T.R. Tatarchuk, V.I. Tsinurchyn, WPhys. Chem. Solid State 21, 300 (2020) (doi:https://doi.org/10.15330/pcss.21.2.300-311).

[35] T. Tatarchuk, A. Peter, B. Al-Najar, J. Vijaya, M. Bououdina, Photocatalysis: Activity of Nanomaterials, in: C.M. Hussain, A.K. Mishra (Eds.), Nanotechnol. Environ. Sci., (Wiley-VCH Verlag GmbH \& Co. KGaA, Germany, Weinheim, 2018). (doi:10.1002/9783527808854.ch8).

[36] R. Chen, X. Zhang, H. Liu, X. Song, Y. Wei, RSC Adv. 5, 76548 (2015) (doi:10.1039/c5ra13586a).

[37] Q. Wang, J. Lian, Q. Ma, Y. Bai, J. Tong, J. Zhong, R. Wang, H. Huang, B. Su, New J. Chem. 39, 7112 (2015) (doi:10.1039/c5nj00987a).

[38] L. Zou, X. Shen, Q. Wang, Z. Wang, X. Yang, M. Jing, J. Mater. Res. 30, 2763 (2015) doi:10.1557/jmr.2015.263.

[39] A. Alshammari, A. Bagabas, M. Assulami, Arab. J. Chem. 12, 1406 (doi:10.1016/j.arabjc.2014.11.013).

[40] N. Guo, H. Liu, Y. Fu, J. Hu, Optik (Stuttg) 201, 163537 (2019) (doi:10.1016/j.ijleo.2019.163537).

\author{
Н. Данилюк, Т. Татарчук, О. Шийчук
}

\title{
Оцінка швидкості фотокаталітичної деградації за допомогою смартфону
}

ДВНЗ «Прикарпатський наџіональний університет імені Василя Стефаника», Івано-Франківськ, Украӥна, e-mail: danyliuk.nazariy@gmail.com

\begin{abstract}
Представлено простий метод перевірки активності фотокаталізатора. Фотокаталітичну деградацію модельного барвника вимірювали за допомогою смартфона. Зміни кольору реєстрували безпосередньо в мікрофотореакторі. Модельний барвник Родамін В розкладався під дією ультрафіолетового опромінення (365 нм). Досліджено вплив концентрації $\mathrm{H}_{2} \mathrm{O}_{2}$ та маси фотокаталізатора діоксиду титану на фотокаталітичну деградацію родаміну Б. Серед трьох колірних систем, RGB, CIE L*a*b* та HSV, перша виявилася найбільш придатною для визначення барвника. Контрольні вимірювання проводили за допомогою UV-Vis спектрофотометра. Випробувано два смартфони та два планшети з різною роздільною здатністю камери. Найкраща калібрувальна крива була отримана за допомогою смартфона Samsung Galaxy A6 з 16-мегапіксельною камерою. Встановлено, що між концентраціями виміряними смартфоном та спектрофотометром, немає суттєвих відмінностей. Значення відносного середньоквадратичного відхилення вимірювань на смартфоні становить менше 0,5\%. Отже, запропонований метод швидкої оцінки активності фотокаталізатора може бути використаний для контролю реакцій фотоокислення.
\end{abstract}

Ключові слова: смартфон, родамін В, фотокаталізатор, світлодіод, фотодеградація. 